\title{
Wyrok Sądu Kościelnego we Włocławku (c. Gręźlikowski) w sprawie o nieważność małżeństwa z tytułu niezdolności psychicznej (...)
}

Ius Matrimoniale 12 (18), 167-188

2007

Artykuł został opracowany do udostępnienia w internecie przez Muzeum Historii Polski w ramach prac podejmowanych na rzecz zapewnienia otwartego, powszechnego i trwałego dostępu do polskiego dorobku naukowego i kulturalnego. Artykuł jest umieszczony w kolekcji cyfrowej bazhum.muzhp.pl, gromadzącej zawartość polskich czasopism humanistycznych i społecznych.

Tekst jest udostępniony do wykorzystania w ramach dozwolonego użytku. 
Ius Matrimoniale 12 (18) 2007

\section{Wyrok Sądu Kościelnego we Włocławku (c. Grężlikowski)}

w sprawie o nieważność małżeństwa z tytułu niezdolności psychicznej (osobowościowej) pozwanej do podjęcia istotnych obowiązków małżeńskich (kan. 1095, n. 3) oraz symulacji zgody małżeńskiej po stronie pozwanej (kan. 1101 §)

\section{Przebieg sprawy}

N. N. zawarły małżeństwo sakramentalne 19 stycznia 1991 roku we Włocławku. Okres znajomości przedślubnej między stronami trwał bardzo krótko, gdyż niespełna rok czasu. Przebiegał w miarę prawidłowo i entuzjastycznie, dało się zauważyć wielkie zauroczenie powoda pozwaną. Bardzo zbliżył strony wspólny wypadek samochodowy jaki miał miejsce na początku znajomości, na skutek którego strony razem przebywały przez dwa miesiące w szpitalu. Pozwana wychowywała nieślubnego syna, urodzonego w 1988 roku, o czym powód wiedział. Zarówno rodzice powoda, jak i matka pozwanej byli przeciwni tak szybkiemu zawarciu małżeństwa. Jednak powód uważał, że nic nie szkodzi na przeszkodzie, aby zawarł małżeństwo z pozwaną, bo ją kocha i chcą razem ze sobą być.

Po zawarciu małżeństwa strony zamieszkały u matki pozwanej i mieszkały tam przez okres około trzech lat, wyjeżdżając co jakiś czas do pracy w Belgii. Będąc w Belgii między stronami układało się dość dobrze i strony były z siebie zadowolone, aczkolwiek pozwana miała pretensje do powoda, że nie chce porządnie pracować, że się obija, nie szuka pracy w Polsce. Podczas przyjazdów do Polski między stronami dochodzi do kłótni i nieporozumień, szczególnie jak urodziło się ich dziecko. Zaczęły się problemy o kwestie finansowe. W tym czasie, zdaniem powoda, pozwana okazała się osobą niezrównoważoną psychicznie i niezdolną do funkcjonowania we wspólnocie małżeńskiej. Była, jego zdaniem wybuchowa, bardzo nerwowa i kłótliwa, agresywna, uparta i nie radząca sobie $z$ obowiązkami małżeńskimi. Poważne nieporozumienia małżeńskie między stronami zaczęly się w pod koniec roku 1993, kiedy to pozwana zaczęła sama wyjeżdżać do Belgii w ce- 
lach handlowych, zostawiając powoda samego z dwójką małych dzieci. Powód zaczął pozwaną podejrzewać o zdrady małżeńskie i o to, że w Belgii ma innego mężczyznę, pozwana zaś początkowo odrzucala te oskarżenia, ale potem przyznała się do zdrad małżeńskich z żonatym, bogatym mężczyzną w Belgii. Powiedziała też powodowi, że ślubowała z nim tylko dlatego ażeby jej panieńskie dziecko miało ojca. Powód zaczął również posądzać pozwaną o branie narkotyków i nadużywanie alkoholu, co szczególnie miało mieć miejsce wtedy jak sama wyjeżdżała do Belgii. Pozwana natomiast zarzuca powodowi, że jest niedorajdą życiowym i „dużym chłopcem”, niezdolnym don utrzymania rodziny, jak też podejrzewa go o zdrady małżeńskie. Na początku 1994 roku między stronami dochodzi do całkowitego zerwania wspólnoty małżeńskiej. Pozwana nakazała powodowi wyprowadzić się z mieszkania jej matki, które razem zajmowali i podejmuje znajomość z innym mężczyzną. Po wyprowadzeniu się od pozwanej powód podejmowal próby pogodzenia się, ale na skutek wyraźnej niechęci pozwanej, nie przyniosly one oczekiwanego przez powoda rezultatu.

W sumie małżeństwo stron trwało okolo trzech lat. Początkowo był to okres raczej udany i przebiegający zgodnie i w zrozumieniu, później natomiast między stronami zaczęly powstawać konflikty i nieporozumienia, wzajemne podejrzenia o zdrady małżeńskie, żale i pretensje o niemożność stworzenia prawdziwej wspólnoty malżeńskiej i rodzinnej. Z powództwa powoda, strony w roku 1995 uzyskaly rozwód cywilny, który orzeczona bez orzekania o winie.

Pod koniec roku 2000 powód wniósł do Sądu Kościelnego we Włocławku prośbę o orzeczenie nieważności swego małżeństwa sugerując niedojrzalość osobowościową pozwanej do podjęcia obowiązków malżeńskich oraz jej symulację zgody małżeńskiej poprzez zawarcie z nim małżeństwa tylko ze względu na to, aby jej dziecko panieńskie miało ojca. Trybunał Włocławski po uznaniu swej kompetencji i przeprowadzeniu krótkiego postępowania informacyjnego dekretem z lipca 2001 roku przyjąl prośbę powodową do przewodu sądowego z tytuły osobowościowej niezdolności pozwanej do zawarcia małżeństwa i podjęcia obowiązków małzeńskich (kan. 1095,3) oraz jej symulacji zgody małżeńskiej (kan. 1101, 1).

W postępowaniu dowodowym przesłuchano strony oraz ośmiu świadków. Powolano także biegłego sądowego celem wystawienia opinii co do psychicznej (osobowościowej) zdolności pozwanej do zawarcia małżeństwa i podjęcia obowiązków małżeńskich. Powódka nie 
poddała się badaniu psychologicznemu, stąd opinię o jej zdolności do zawarcia małżeństwa i podjęcia obowiązków małżeńskich biegły sądowy wystawił na podstawie akt sprawy.

Dekretem z maja 2002 roku ogłoszono publikację akt sprawy. Po wniesieniu uwag przez strony i decyzji pozwanej, iż podda się badaniu psychologicznemu, dekretem z czerwca tegoż roku powolano ponownie biegłego sądowego celem przeprowadzenia badania psychologicznego pozwanej i wystawienie opinii o jej zdolności do zawarcia malżeństwa. Po uzupełnieniu materiału dowodowego, dekretem z lipca 2002 roku zamknięto postępowanie dowodowe i przystąpiono do wyrokowania. Po upływie terminu przewidzianego na przejrzenie akt sprawy przez Kolegium Sędziowskie i sporządzenie swoich votów oraz na przygotowanie uwag przedwyrokowych przez Obrońcę Węzła Malżeńskiego, przystąpiono do rozstrzygnięcia sprawy i wydania wyroku, co miało miejsce we wrześniu 2002 roku.

\section{Motywy prawne}

1. Niezdolni do zawarcia matzeństwa sa ci, którzy [...] z przyczyn natury psychicznej nie sa zdolni podjać istotnych obowiąków malzenskich (kan. 1095,3).

Przez ową niezdolność do podjęcia istotnych obowiązków małżeńskich wynikającą z przyczyn natury psychicznej należy rozumieć niezdolność do realizowania przedmiotu zgody małżeńskiej. Chodzi zatem o sytuacje, w których dany podmiot zawierający małżeństwo, jakkolwiek posiada używanie rozumu, jest inteligentny, wie czym jest i do czego zobowiązuje małżeństwo, to jednak na skutek zaburzeń natury osobowościowej (psychicznej) nie jest w stanie podjąć, a tym samym wypełnić istotnych obowiązków małżeńskich, nie jest w stanie przekazać przedmiotu zgody małżeńskiej. Trzeba bowiem pamiętać, że matzenstwo to glęboka wspólnota zycia i mitości powstata z aktu osobowego, przez który matżonkowie się sobie oddaja i przyjmuja, świadcza sobie pomoc i postuge w zrozumieniu i mitości, zespalaja się $w$ dzialaniu, troszcza o wzajemne dobro, doświadczaja jedności oraz osiagaja coraz petniejsze zjednoczenie (zob. Gaudium et spes, nr 49).

Wynika z tego jednoznacznie, że kto zawiera małżeństwo musi swoimi możliwościami psychicznymi, emocjonalnymi i osobowościowymi gwarantować, że wywiąże się z przyjętych na siebie zobowiązań, jakie 
niesie ze sobą wspólnota małżeńska. Wynika to także z kodeksowego określenia małżeństwa. Małżeństwo bowiem, według określenia Kodeksu Prawa Kanonicznego (kan. 1055,1), jest przymierzem mężczyzny i kobiety, którzy tworzą ze sobą wspólnotę całego życia, skierowaną ze swej natury do dobra małżonków oraz zrodzenia i wychowania potomstwa. Istotnymi przymiotami małżeństwa są jedność i nierozerwalność (kan. 1056).

Zawierający zatem małżeństwo musi być zdolny do nawiązania relacji interpersonalnych we wspólnocie małżeńskiej, a także do przekazania drugiej stronie prawa do wlaściwej wspólnoty życia, dobra wspólmałżonka, samodoskonalenia się i rozwoju duchowo-somatycznego, dochowania wierności, nierozerwalności, pielęgnowania wspólnoty życia, świadczenia pomocy wspólmałzonkowi. Musi być zdolny do podjęcia istotnych obowiązków małżeńskich. Niezdolność do podjęcia tych obowiązków i praw, wszystkich lub jednego z nich, powoduje nieważność małżeństwa, bowiem jak pisze ks. prof. Wojciech Góralski, niezdolność do podjecia istotnych obowiazków malżeńskich przejawia się w każdym poważnym zaktóceniu osobowości kontrahenta, wskutek którego to zaklócenia niemożliwe jest normalne ustanowienie wspólnoty matzenskiej, stużacej do wzajemnego doskonalenia się $i$ dopetniania matżonków. Przyczyny niezdolności podjęcia tych obowiązków małżeńskich tkwią albo w człowieku z racji jego struktury psychicznej, psychofizycznej, albo są nabyte z racji pewnych niewłaściwych okoliczności (niezdolność osobowościowa). Do pierwszej grupy można zaliczyć te, które tkwią w sferze psychoseksualnej. Druga grupa obejmuje zakłócenia osobowości, które uniezdalniają nupturienta do właściwych i normalnych zachowań małżeńskich, do relacji międzyosobowych, interpersonalnych i mieszczą się w określeniu „wspólnota całego życia”. O tej drugiej grupie niezdolności mamy do czynienia w niniejszej sprawie małżeńskiej.

Tylko wówczas małżeństwo jest nieważne, gdy stwierdzi się u któregoś z zawierających małżeństwo jakąś anomalię psychiczną czy osobowościową, czy też zahamowanie lub zaburzenie osobowości. Jednakże same zaburzenia, zahamowania czy choroby psychiczne mogą być różne w swych przejawach, formach i postaciach. Jedne mogą czynić kontrahenta niezdolnym do zawarcia małżeństwa i podjęcia istotnych obowiązków małżeńskich, inne nie. Stwierdzenie w danym przypadku wystąpienia w momencie zawierania małżeństwa - niezdolności podjęcia istotnych obowiązków małżeńskich z przyczyn natury psychicznej (osobowościowej), jest czymś bardzo trudnym. Dużą rolę w ustalaniu przyczyn owej 
niezdolności psychicznej czy osobowościowej do podjęcia istotnych obowiązków małżeńskich posiada biegly sądowy, którego Sąd Kościelny powołuje do każdej tego typu sprawy, ażeby autorytatywnie i z fachowością oraz znawstwem psychologii i psychiatrii orzekł ewentualną niezdolność do funkcjonowania danej osoby we wspólnocie małżeńskiej (por. kan. 1574 i $1680 \mathrm{KPK}$ ). Należy tutaj pamiętać o przemówieniu Ojca Swiętego Jana Pawła II do pracowników Roty Rzymskiej z 5 lutego 1987 roku i 25 stycznia 1988 roku, w którym to papież stwierdził, że biegli według swojej kompetencji winni ocenić zdolność osoby do podjęcia istotnych obowiazków matzeńskich (AAS 79/1987/s. 1454; AAS 80/1988/s. 1182). Nie zwalnia to jednak sędziego $z$ obowiązku weryfikacji założeń antropologicznych zawartych w opiniach biegłych, w świetle zasad antropologii chrześcijańskiej. Może on bowiem przenieść pole ocen i decyzji kanonistyczno-sądowych na ustalenia i rozstrzygnięcia bieglych co do niezdolności kontrahenta do podjęcia obowiązków małżeńskich jedynie przy zaistnieniu poważnej formy anomalii psychicznej (por. AAS 79/1987/s. 1457), bo tylko ciężse formy psychopatologii) moga naruszyć psychiczna zdolność osoby $w$ dązeniu ku wartościom transcendentnym (por. AAS 80/1988/s. 1180). Zatem kryterium weryfikacji nie może być wizja idealnej osoby czy też osobowości ludzkiej we wszystkich jej pozytywnych cechach, ale przede wszystkim możliwość realizowania przez osoby, które zawarły małżeństwo, wlaściwych relacji interpersonalnych w małżeństwie, a także realizowanie wspólnoty małżeńskiego życia.

Zatem sędzia kościelny w tego typu sprawach obowiązany jest wniknąć we wszystkie okoliczności poprzedzające zawarcie małżeństwa, jego zawarcie oraz poślubne, rozpatrując je łącznie $z$ konkluzjami przedstawionymi przez biegłego, a także biorąc pod uwagę zeznania stron i świadków. Jednocześnie zadaniem sędziego jest analiza wszystkich zebranych dowodów oraz ocena, czy wskazują one (czy też nie) na wystąpienie u kontrahenta poważnej anomalii powodującej niezdolność do podjęcia istotnych obowiązków małżeńskich. W świetle powyższych zasad - według ks. A. Stankiewicza - dokonuje się zarówno ocena ciężkości zjawiska psychopatologicznego stojącego u podstawy zaskarżonej w sądzie niezdolności psychicznej (osobowościowej), jak również transpozycja ustalonej przez biegłego anomalii psychicznej w kategorii niezdolności do podjęcia określonego obowiązku małżeńskiego, np. w odniesieniu do podjęcia obowiązku nawiązania relacji interpersonalnych w ramach wspólnoty życia małżeńskiego, do przyjęcia obowiązku wspólnoty życia specyficznie małżeńskiego. 
W świetle powyższego należy pamiętać, że małżeństwo staje się nieważnie zawarte jedynie na skutek niezdolności psychicznej lub osobowościowej kontrahenta do podjęcia obowiązków małżeńskich, a nie na skutek trudności realizowania prawdziwej wspólnoty życia, dobra i miłości we wspólnocie małżeńskiej. Niezdolność psychiczna, osobowościowa, aby mogła być przyczyną nieważności małżeństwa musi być rzeczywista i ciążka, udowodniona w postępowaniu procesowym, a także uprzednia, tzn. istnieć już przed zawarciem małżeństwa. Niezdolność psychiczna (osobowościowa) powstała po zawarciu małżeństwa i w czasie jego trwania nie może być przyczyną nieważności małżeństwa.

(Por. W. Góralski, Niezdolność do podjęcia obowiazków malżeńskich (próba analizy kan. 1095, nr 3), Ius Matrimoniale 1990, s. 58-93; A. Stankiewicz, Sędzia $i$ biegly w sprawach o nieważność matżeństwa z tytulu niezdolności psychicznej, Ius Matrimoniale", 1994, s. 59-66; R. Sztychmiler, Istotne obowiazki malzeńskie, Warszawa 1997; W. Krupa, Zasady opracowywania opinii biegłego psychologa w sprawach o nieważność małżeństwa, „Ius matrimoniale, t. 5-6, Warszawa 1996, s. 137-142; W. Góralski, Problem niezdolności relatywnej do podjęcia istotnych obowiązków malzenskich (kan. 1095, nr $3 \mathrm{KPK}$ ) w świetle orzecznictwa Roty Rzymskiej, Ius Matrimoniale 1998, s. 75-87).

2. Domniemywa się, że wewnętrzna zgoda odpowiada stowom lub znakom użytym przy zawieraniu malżenstwa. Jeżeli jednak jedna ze stron albo obydwie pozytywnym aktem woli wykluczalyby samo matzeństwo lub jakiś istotny element matżeństwa albo jakiś istotny przymiot, zawieraja je nieważnie (kan. 1101 KPK).

Małżeństwo powstaje przez umowę między małżonkami, przez ich zgodę małżeńską, ale w swej istocie jest instytucją niezależna od ich woli; jest aktem osobowym, przez który małżonkowie wzajemnie się sobie oddają i przyjmują. Stąd prawidłowość i skuteczność prawna zgody małżeńskiej wymaga, aby wewnętrzna wola stron była zgodna z tym, co przez zawieranie małżeństwa na zewnątrz wyrażają, tzn. ażeby nie tylko zawierała szczerą intencję zawarcia małżeństwa, ale również akceptowała wszystkie istotne elementy i właściwości - przymioty małżeństwa. Normalnie i zazwyczaj tak bywa. Zdarza się jednak - jak i w tym przypadku zachodzi tego podejrzenie - że przy zawieraniu małżeństwa zachodzi brak szczerości i rozdźwięk między wolą ślubującego, która jest wprost sprzeczna z zewnętrznym oświadczeniem woli albo nie daje się pogodzić czy to z istotnym celem malżeństwa czy jego istotnymi cechami. 
Jak wynika z przytoczonego przepisu kanonu 1101 KPK, zgoda malżeńska może być upozorowana całkowicie, jeżeli kontrahent zawierając małżeństwo pozytywnym aktem woli wyklucza w ogóle samo małżeństwo, lub upozorowana częśsiowo, jeżeli zawierający małżeństwo pozytywnym aktem swej woli wyklucza jakiś istotny element lub przymiot małżeństwa (wierność, nierozerwalność, jedność, wspólnotę życia, dobro wspólmałzonka, potomstwa) Przymioty te wynikają z samej istoty małżeństwa, stąd są ważne i konieczne do zaistnienia obowiązującego i ważnego małżeństwa. Jeżeli któraś ze stron wykluczałaby pozytywnym aktem woli powyższe przymioty czy elementy, zawierałaby nieważnie swoje małżeństwo. Problem jednak w tym, ażeby przewód sądowy jednoznacznie wykazał i udowodnił z moralną pewnością, że w chwili zawierania małżeństwa u którejśs ze stron, albo u obydwu byla takie wykluczenie pozytywnym aktem woli samego małżeństwa lub jego istotnego przymiotu lub elementu. Postępowanie dowodowe musi to udowodnić z całą pewnością. Na domysłach i przypuszczeniach Sąd Kościelny nie może budować domniemania o nieważności małżeństwa.

Dowodzenie symulacji konsensu małżeńskiego, czy to całkowitej czy częściowej, nie jest latwe, a to z uwagi na konieczność poznania aktu wewnętrznego, często mało znanego zewnętrznie, a także i wewnętrznie. W dowodzeniu bierze się pod uwagę następujące elementy i argumenty: przyznanie się strony symulującej zgodę na małżeństwo, przyczyna skłaniająca do symulacji, okoliczności dotyczące kojarzenia się małżeństwa, jego zawierania, zachodzące po ślubie, które w sposób jednoznaczny wskazują na to, że dane małżeństwo zostało zawarte nieszczerze $\mathrm{z}$ wykluczeniem wspólnoty małżeńskiej, jak i istotnych elementów i przymiotów małżeńskich. Wszystkie dowody winny występować łącznie, gdy zabraknie jednego z nich, dowodzenie staje się bardzo trudne.

(Zob. W. Góralski, Kanoniczna zgoda małżeńska, Gdańsk 1991, s. $158-189)$.

\section{Motywy faktyczne}

Twierdzenia i zeznania powoda:

Pozwana poznatem we Wtoctawku w roku 1990. Byta wtedy panna $z$ dzieckiem, które urodzone byto w 1988 roku /.../ wpadta mi w oko i bardzo się w niej zakochatem. W czerwcu 1990 roku mieliśmy wypadek 
samochodowy $i$ przez dwa miesiace razem leżeliśmy $w$ szpitalu. To nas jeszcze bardziej przybliżyto i dalej kontynuowaliśmy znajomość /... . Ja ja kochatem $i$ uważatem, że będzie dobra żona /.../. Mimo sprzeciwów rodziców i tłumaczenia jej matki, abyśmy poczekali z pobraniem się, postanowitem zawrzeć matżeństwo /... . Slubowatem szczerze $i$ prawdziwie, zgodnie z nauka Kościoła, dobrowolnie. Uważatem, że wszystko nam się dobrze utoży, gdyż sie kochamy i pasujemy do siebie /.... Poczatkowo nasze pożycie matżeńskie uktada sie poprawnie, zamieszkaliśmy w mieszkaniu matki pozwanej /.../. Po paru miesiacach od zawarcia matzeństwa wyjeżdzamy razem do Belgii pracować, ażeby zarobić troche pieniedzy 1.../. Co pare miesiecy przyjeżdzaliśmy do Polski i jakośs się żyto. W miedzyczasie pozwana urodzila nasze dziecko /.../. Okoto dwa i pót roku po ślubie zaczynają się między nami nieporozumienia $i$ konflikty oraz problemy, szczególnie wtedy kiedy byliśmy w Polsce. Przede wszystkim w gre wchodza sprawy finansowe, pretensje żony, że za mato pracuje i jestem leniwy, że nie za bardzo troszcze się o byt materialny, jak to czynia inni męzczyźni /... . Pozwana sama zaczyna wyjezdżać do Belgii handlować, wyjeżdzala na parę dni, a wracala po dwóch tygodniach. Poprzez znajomych w Belgii dowiedziatem sie, że żona mnie w Belgii zdradza z innym męzczyzna. Kiedy spytatem ja o to, to powiedziala, że ma w Belgii jakiegoś bogatego męzczyznę, który ma dużo pieniędzy, byl on żonaty $i$ mial dwoje dzieci /.../. Zona wtedy powiedziata mi również, że ślubowata ze mna tylko dlatego, aby jej panieńskie dziecko miato ojca, powiedziata, że mnie nigdy nie kochata $i \dot{z}$ e nie ma szans, aby nasze matżenstwo trwato dalej /.../. Byto to na początku 1994 roku, przez jakiś czas jeszcze mieszkaliśmy razem, ale pozwana nie traktowata mnie już jako swego męża. Wymeldowata mnie z mieszkania swej matki $i$ kazata wyprowadzić sie /.../. Ja podejmowatem próby ratowania swego matżeństwa, pracowatem dorywczo, prositem ja, przepraszatem, ale ona podjeła za mnie decyzje $i$ wystapita sadownie o alimenty, wtedy wiedziatem, że nie ma szans abyśmy byli razem. Przeprowadzitem się do swoich rodziców do Wloclawka, sama pozwana mnie spakowała i nie chciała ze mna być/... . Nie wiem do dzisiaj co byto przyczyna jej takiego postepowania i nagłej zmiany uczuć i postępowania w stosunku do mnie, uważam jednak że przyczyna takiego zachowania pozwanej tkwila w jej niezrównoważonej osobowości, braku dojrzalości do petnienia roli żony i matki, a także traktowanie malżeństwa nie jako wspólnoty nierozerwalnej /.... Mam też dzisiaj poważne watpliwości jak pozwana ślubowata, uważam, że tak naprawdę tego matzeństwa nie chciata /.... 


\section{Twierdzenia i zeznania pozwanej:}

Okres naszej znajomości przedślubnej trwat dość krótko, bo okoto pót roku /.../ darzyliśmy się uczuciem mitości, oboje dążliśmy do spotkań 1.../. Powód bardziej dażyl do zawarcia matzeństwa i mimo, że moja mama prosita, abyśmy ślubowali troche później, powód postanowit, że zawrzemy matzeństwo szybciej, on też zaproponowat zawarcie malżenstwa 1.... Jak ślubowaliśmy ja miatam 23 lata, powód zaś 24 lata. Ja pracowatam $w$ Przychodni Zdrowia jako laborantka, powód natomiast handlowat. Mieliśmy dość dobre warunki materialne /.../. Planowaliśmy normalne matżenstwo, miato to być matzeństwo zgodne z nauka Kościola /.../ powód byl człowiekiem bardzo zrównoważonym, spokojnym, ja też miatam pewna stabilizacje i uważatam, że bedzie nam dobrze razem w malżeństwie /.../. Mialam dziecko panieńskie, o czym powód wiedzial. Nie mówitam mu kto jest ojcem tego dziecka /.../. Slubowatam szczerze $i$ prawdziwie, dobrowolnie, świadomie $i$ bez przymusu, chcialam tego malzeństwa /... Po zawarciu malżeństwa zamieszkaliśmy razem w mieszkaniu mojej matki /.../ zaraz po ślubie nasze pożycie malżeńskie uktadato sie wspaniale $i$ pięknie, byto nam ze sobq bardzo dobrze /.../. $W$ dwa miesiace później wyjechaliśmy do Belgii kienujac sie wzgledami materialnymi, chcieliśmy zarobić troche pieniedzy /.... Mąz nie lubit sie jednak przemeczać /.../ nie szukat pracy, byto mu zawsze dobrze, ta ja musiatam zawsze mieć inicjatywe i troszczyć się o wszystko /... Mimo wszystko $w$ naszym malżeństwie panowata atmosfera dobra, szanowaliśmy sie 1... . Po dwóch latach zaczęliśmy się zdradzać nawzajem, tym samym sie rozstalismy. Powodem zdrad matzeńskich byly nieporozumienia $w$ domu, pretensje, wzajemne żale i któtnie. Wszystko to miato miejsce po naszym powrocie z Belgii. Wcześniej przez okres dwóch lat wspólnie o siebie dbaliśmy i kochaliśmy się /.../. Któtnie i pretensje, zdrady matżeńskie zaczęty się od momentu kiedy zaczęto brakować nam pieniędzy /.../. Bezpośrednia przyczyna rozejścia się bylo to, że ja poprositam męza aby wyprowadzit sie, stwierdzitam że nie chce mieć trzeciego dziecka $w$ domu, mąz bowiem tak się zachowywat nie troszczac się i nie przejmując niczym w naszym matżenstwie 1.... Używam trzecie dziecko w stosunku do męża w kontekście utrzymania materialnego /.../. Próbowaliśmy się pogodzić, ja podejmowatam takie próby, ale nie przyniosty one żadnego rezultatu /.../. Po wyprowadzeniu sie ode mnie powoda, zaczelam spotykać sie z innym mezzczyzna. Nie byt to ojciec mego nieślubnego dziecka /.... Jest prawda, że kazalam wyprowadzić sie powodowi z mieszkania mojej mat- 
$k i$, gdyż już nie rozumieliśmy się, nie zgadzaliśmy i nie byto czego ratować $z$ naszego matzeństwa /... J. Ja jestem osoba zdrowa psychicznie, jestem osobq odpowiedzialnq za swoje czyny $i$ dziwie się, że powód posadza mnie o niezrównoważeni psychiczne czy patologie osobowościowe, nie ma ku temu żadnych podstaw ażeby tak twierdzić /.../. Nie jest też praw$d q$, że nadużywatam kiedykolwiek alkoholu czy bytam uzalezniona od narkotyków /....

\section{Zeznania świadków:}

\section{A/ Matka Powoda:}

Od samego początku nie podobała mi się ta znajomość syna /.../. Mówit mi, że pozwana ma dziecko panieńskie, bylam nastawiona negatywnie na te znajomość syna i sama mu powiedziatam, aby raczej zerwat te znajomość /.... Sami podjęli decyzje o zawarciu malzenstwa /.... Byli zadowoleni ze znajomości, byli za sobą i koniecznie chcieli zawrzeć matżenstwo /... O. Okres narzeczeński trwat okoto pięciu miesięcy. Spotykali sie ze soba $i$ widać bylo, że sie kochaja 1.... Myśle, że strony świadomie $i$ dobrowolnie wyrażaly wole zawarcia matzeństwa /.... Po ślubie strony zamieszkaly u mnie, mieszkali tutaj okoto dwóch miesiecy, potem wyjechali do jej mamy. Byto widać, że darza się uczuciem mitości $i$ sympatii, ze sie rozumieja /.... W 1993 roku zaczęly sie problemy między stronami, wtedy syn zacząt czéściej przyjeżdzać do domu. Synowa wyjechata do Belgii, zostawiając mego syna z dwójka małych dzieci /.../, po jej powrocie $z$ Belgii, syn powiedziat, że w ich matżenstwie dzieje się źle, nie chciat mówić o szczegótach, powiedział, że pozwana już go nie kocha i przeszła jej mitość do niego /.../ domyślatam się, że chodzi o zdrady matzeńskie synowej $i$ jej brak odpowiedzialności /.... Strony ostatecznie rozeszly się wtedy, kiedy pozwana poznata innego męzczy6zne $i$ to faktycznie bylo przyczynq ostatecznego rozejścia sie stron /... /. Z tego co wiem, to na utrzymanie rodziny pracowat syn, a synowa pracowata dorywczo w Belgii, pozwana w Polsce nie pracowata /.../. W końcu pozwana kazała synowi wyprowadzić się z mieszkania jej matki, gdyż nie byt dla niej wygodny. Już wówczas spotykata sie z innym meżczyznq $w$ ich mieszkaniu $i$ dlatego chciała sie pozbyć syna /.../. Jest prawda, że pozwana byla osoba uzależniona od narkotyków. Wedlug mnie byla osoba troche niezrównoważona, czy była to choroba psychiczna, tego nie wiem /.../. 


\section{B/ Brat Powoda:}

Ich znajomość trwata bardzo krótko, chyba niecaly rok/.../. Rodzina odradzała powodowi prowadzenie tej znajomości $i$ zawarcie matżenstwa 1... Z Z tego co pamietam, to byty anonimowe telefony odradzajace bratu to matzenstwo, byly to telefony mówiace, że pozwana ma nie pouktadane w glowie, że lubi mężczyzn /.../, brat wiedziat te z, że pozwana ma dziecko z innym mężcyzna, z kim tego nie wiedziat, gdyż nie chciała mu powiedzieć /.../. Powód bardzo chciat tego matzeństwa mimo, że mu odradzaliśmy, byta to jego samodzielna decyzja /.../. Z pozwana przed slubem nie miałam żadnego kontaktu, dlatego nie wiem jak ona ślubowala, raczej $z$ tego co styszatem, chciala tego matżeństwa /.../. Po ślubie brat przeprowadzi $t$ sie do niej, z tego co opowiadala mi matka, to początkowo widać byto, że byto to zgodne matzeństwo /.../. bytem też u nich po ślubie kilka razy, widziatem wtedy, ze między nimi wszystko jest w porzadku /.... Do pracy wyjeżdzali zagranice /.../potem tylko chyba ona wyjeżdzala o brat zajmowat sie dwójka dzieci, ona natomiast miała pretensje, że brat nie podjąl jakiejś pracy /.... Jej wyjazdy byly okazjo do jej zdrad malżeńskich, gdyż jak się później okazato to wyjeżdzata z innym mężczyznq do Beloii do pracy $i$ tam zdradzata brata /.../, byto to gdzieś dwa lub trzy lata po ślubie 1.../. Brat chcial jej przebaczyć, ale ona już nie chciała brata /.... Brat mówit mi, ze pozwana brata silne leki i one dawaly skutek jak narkotyki, byto to już pod koniec ich matzenstwa i niebawem nakazata bratu, aby wyprowadzit sie z jej mieszkania /.../. Moim zdaniem powodem rozpadu matżenstwa byty zdrady matzeńskie jakich dopuszczata sie pozwana, poza tym byta nieodpowiedzialna i niepowaznie traktowata wspólnote matzeńska /.../, poznata troche świata i mąz oraz dzieci nie byli jej potrzebni, chciata się bawić i używać świata /.../.

\section{C/Znajoma Stron:}

Rodzice odradzali powodowi zawarcie matżeństwa, gtównie ze względu na to, że pozwana byla panna z dzieckiem /.../. Nikt jednak kategorycznie mu nie zabronit, sam podją decyzję o zawarciu matżenstwa /.../. Jej rodzina mówita powodowi, że pozwana jest osoba nieodpowiedzialnq, szukajaca lekkiego i tatwego zycia, ale powód tego nie stuchat, byt bardzo w niej zakochany /.../. Slyszalam, ze pozwana byla na odwyku, ze brala narkotyki, z tym że nie wiem czy brata je przed czy po ślubie /.../. Pozwa- 
na czesto przyjeżḋata do Wtoctawka do powoda, wydaje mi sie, że jej bardzo zależato na zawarciu tego matżeństwa, aby nie być panna z dzieckiem /.../. Myśle, że oboje slubowali szczerze $i$ dobrowolnie, czynili to chętnie /.../. Po ślubie powód przepisat na siebie jej dziecko i dat mu swoje nazwisko, niebawem po ślubie urodzila pozwana ich dziecko, potem wyjechali do Belgii do pracy, aby zarobic pare groszy /.../. Byli tam nie za dlugo, potem ona sama wyjezdżala do Belgii handlować i pracować, tam te ż zaczęty się zdrady malżenskie, gdyż tam poznata innego mężczyzne 1.... Jak wrócita do Polski to ten pan zamieszkał u niej w mieszkaniu, a powodowi kazała sie wyprowadzić i go wymeldowata /.../. Styszatam, że pozwana brata narkotyki, kiedy jednak zaczela je brać, tego nie wiem /.../, styszalam też ze obecnie jest niepelnosprawna fizycznie, gdyż przedawkowata narkotyki i jest niezdolna do pracy /.../ Wiem, że powód jeździl do niej do szpitala, chciat jeszcze wtedy ratować matżenstwo, tak byt za nia, zabieral dzieci do siebie na dlużej, ale ona nie chciata z nim pogodzić się i zamieszkać, wolala innego mężzyznę /.../.

\section{D/Znajoma Stron:}

Po ślubie wyjeżdzali do pracy do Belgii i potem wracali do siebie /.../ potem pozwana sama wyjeżdzata do Belgii, gdyż zajmowata się handlem $i$ wtedy poznata innego mężczzne /.../, wtedy też zaczęto się źle dziać $w$ ich malzenstwie. Byto to gdzieś okoto trzech lat po zawarciu malżenstwa /... Z Z tego co wiem, to ona już wcześniej z tym męzczyzna zdradzata powoda, tylko on o tym nie wiedziat /.... Styszatam, że pozwana brata narkotyki, nawet doszto do tego, że musiata iść do szpitala na odtrucie, ale byto to juz po ich rozwodzie /.../. Ona jeszcze przed ślubem obracata sie $w$ nieciekawym towarzystwie, stad mogła $i$ wcześniej brać narkotyki /.... Żal mi powoda, bo zrobita mu pozwana wielka krzywde /.../.

\section{E/ Stryj Pozwanej:}

Pozwana znam od dziecka, gdyż mieszkata ode mnie o dwa kilometry /.../, ukonczyla technikum chemiczne $i$ nie widziatem u niej negatywnych i nieodpowiedzialnych zachowan /... . Obecnie wykończyla sie fizycznie i psychicznie i ma porażenie ukladu nerwowego, nie może chodzić, a powodem tego bylo nadużywanie alkoholu i zażwanie narkoty- 
ków /.../. Z tego co wiem, przed ślubem nie nadużywata alkoholi i nie brata narkotyków, to dopiero miato miejsce dużo później, najprawdopodobniej jak wyjeżdzata sama do Belgii/.../. Przed zawarciem matżeństwa wszystko przebiegato dobrze i normalnie, bardzo byli mtodzi za soba i chcieli zawrzeć to matzeństwo /.../. Styszatem, że potem pozwana poznata innego mężczyznę $i$ to stato się powodem ich problemów matżenskich /.... Jeśli chodzi o narkotyki, to zaczęla je brać jako mężatka, prawdopodobnie sama je sobie przygotowywata, gdyz byla po szkole

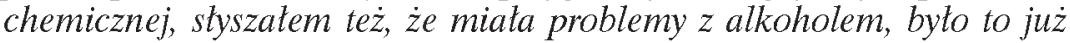
po zawarciu malzeństwa. Może chciała zagluszyć swoje wyrzuty sumienia i zdrady malżeńskie /.../.

\section{F/ Sasiadka Pozwanej:}

Po zawarciu malżenstwa oboje wyjechali do Belgii do pracy /.../ jak wrócili urodziło się ich dziecko /.../. Po jakimś czasie sama zaczęla wyjeżdzać do Belgii, troche handlowata, troche pracowala, a powód zostawal $z$ dziećmi /.../. Byto tak przez okres miej wiecej trzech lat /.... Zarzucata mu brak inicjatywy, to, że nie tatwi sobie pracy /.../, że jest bardzo leniwy /.... Ona byla kobieta dość przedsiębiorcza $i$ zywa /.../, on na wszystko się zgadzat, dlatego co chciata to robita /..... Potem powód zarzucat jej, że sama wyjeżdza, a on sam musi pilnować $i$ wychowywać dzieci $/ . .$. .

\section{G/ Matka Pozwanej:}

Oboje chcieli bardzo tego matżenstwa, ja mówitam powodowi, aby się zastanowit co do tego malżenstwa /.../, powiedziat, że ja bardzo kocha $i$ wszystko inne jest nieważne 1.../. Z tego co wiem, to ślubowali dobrowolnie i zgodnie z nauka Kościota, oboje chcieli tego matżeństwa /.../, byta to ich samodzielna $i$ dobrowolna decyzja /... . Po slubie strony zamieszkaty $w$ moim mieszkaniu. Po okoto trzech miesiacach pojechali oboje do Belgii do pracy, wszystko miedzy nimi uktadato sie dobrze i poprawnie, szanowali się $i$ kochali, uczyli sie jezyka $i$ szukali lepszej pracy 1.../. W sumie zgodnie zyli ze soba okolo trzech lat /.../. Nieporozumienia zaczęly sie na skutek braku pracy, braku pieniedzy, zieć nie kwapit się z szukaniem zatrudnienia, nie przejmowat się, ze nie ma pracy /.... Córka wtedy zaczela wozić towary z Belgii do Polski i handlowata nimi, jeź- 
dzita tam raz $w$ tygodniu /.../. W tym czasie $i w$ tych okolicznościach poznata mężcyzne, zięć $w$ tym czasie siedziat $w$ domu i pilnowat dzieci /.../. Zerwanie wspólnoty matzenskiej spowodowaty sprawy materialne, niechętne szukanie pracy przez powoda $i$ zdrady matzeńskie córki /.... Wedtug mnie wina leży po obu stronach, on nie szukat pracy i byt leniwy, a ona zaczęta go zdradzać /.../. Z tego co wiem, to zaczęta spotykać się $z$ innym mężczyzna okoto dwóch i pót roku po ślubie /.../. Jak wyjeżżata do Belgii handlować to zaczęla troche naduzywać alkoholu i brać jakieś środki wzmacniajace, przynajmniej tak mi mówita /.../. Obecnie ja zajmuje się dziećmi dlatego, że córka jest osoba chorq, sama potrzebuje opieki, jest sparalizowana i ma niedowłady /.../. Tak córka jaki i zięć maja odebrane prawa rodzicielskie, córka gdyż jest chora, zięć bo zbyt mato opiekowat się dziećmi /.../, córka jest zdrowa psychicznie i odpowiada za swoje czyny /.../.

\section{H/ Brat Powoda:}

Brat przed ślubem byt świadomy, że pozwana ma nieślubne dziecko /.../, nie przeszkadzato mu to jednak $i$ zdecydowat sie na zawarcie matżenstwa /.... Po zawarciu matżeństwo, które wedlug mnie zawierali dobrowolnie i zgodnie z nauka Kościota, szczerze, zamieszkali w mieszkaniu jej matki /.../. Brat zajmowat się wtedy handlem obwoźnym, a pozwana nie pracowata, tylko byla wspierana przez matke, która pracowala za granica /.../. Później brat razem z pozwanq wyjechali do Belgii do pracy /.../, wszystko między nimi uktadato się dobrze, byli zgodnym matzeństwem $i$ raczej wtedy szczéśliwym. Nie styszatem żeby coś między nimi nie grato 1.... Potem jak sie dowiedziatem, to okazato sie, że zaczely sie między nimi problemy matzeńskie na skutek zdrad matzenskich pozwanej /.../. Byt on chyba z Warszawy $i$ zaczęli się ze sobq spotykać jak pozwana sama wyjeżdzata do Belgii handlować /... . To definitywnie zniszczyto ich matzeństwo, a raczej jej zte zachowanie, zdrady i nieodpowiedzialnośc /... /. Nie wiem czy pozwana kazala wyprowadzić się bratu, jest jednak faktem, że potem spotykata się z tym innym mężczyzna w swoim mieszkaniu /.../. Slyszatem, ze pozwana robita sobie jakieśs środki chemiczne $i$ je brata, jeszcze pod koniec trwania ich matżenstwa /.../, byta po szkole chemicznej więc wiedziała co robi. Branie jednak tych środków doprowadzito do tego, że obecnie jest na wózku inwalidzkim. Od czasu jej choroby jej nie widziatem /.../. 


\section{Z opinii wystawionych przez Biegłego Sądowego:}

\section{A/. Opinia pierwsza wystawiona na podstawie akt sprawy:}

Bez badania psychologicznego trudno wprost $i$ jednoznacznie określić cechy osobowości pozwanej /.... Jednakże dziecko panieńskie pozwanej, styl $i$ sposób jej zycia, traktowanie matżenstwa i powoda jako męza moga świadczyć o osobowości pozwanej nie w pelni dojrzatej emocjonalnie i uczuciowo /.../. To w jakimś stopniu osobowość pozwanej doprowadzita do zażywania przez nia robionej sobie mieszanki leków, co w konsekwencji doprowadzito pozwana do trwalej choroby porazenia nerwowego konczyn dolnych $i$ trwalych zmian nerwowo-mózgowych /.../. Akta sprawy, zeznania świadków, wskazuja na pewna ograniczona zdolność pozwanej do podjecia obowiazków matzeńskich, co potwierdza nieodpowiedzialne zachowanie i postawa pozwanej w matzenstwie /... . Osoba dojrzata, wlaściwie uksztaltowana osobowościowo nie doprowadzitaby do uzaleznienia od mikstury leków i innych preparatów, które mialy destrukcyjny wplyw na jej samopoczucie, zdrowie i zycie /.../.

B/. Opinia druga (uzupetniajaca) po badaniu psychologicznym Pozwanej:

Pozwana charakteryzuje się osobowościq silna, egocentryczna $i$ niezależna $z$ tendencja narzucania swoich pogladów i podporzadkowywania sobie innych osób /.../ charakteryzuje się żywa i zmienna emocjonalnoscia /... / Osobowość tego typu może mieć trudności w nawiązaniu wtaściwych i prawidtowych relacji interpersonalnych /.../. Pozwana w chwilizawierania malżenstwa raczej nie wykazywata, poza wskazanymi trudnosciami osobowościowymi, w stanie psychicznym istotnych odchylen od normy /.../, w jakimśs stopniu jej osobowość byta nie do końca prawidtowo uksztaltowana, jednakze nie na tyle, ażeby nie byla ona zdolna do podjęcia istotnych obowiazków matzeńskich $i$ do prawidlowego funkcjonowania we wspólnocie matżenskiej /.../. Badanie psychologiczne pozwanej $i$ jej postawa $i$ zachowanie w matżeństwie upowaznia jednak na wskazania i dopatrzenia sie w postepowaniu pozwanej pewnych cech niedojrzalości emocjonalnej, jednak dotyczyly one glownie okresu po zawarciu malżeństwa $i$ nie byly nasilone $w$ takim stopniu, ażeby mogly mieć istotny $i$ jednoznaczny wplyw na osobowościowa zdolność pozwanej do zawarcia i funkcjonowania w matzeństwie /.... 


\section{Wnioski decyzyjne}

Rozpoczynając sądową analizę zgromadzonego materialu dowodowego w niniejszej sprawie małżeńskiej, należy rozpocząć od oceny wiarygodności, prawdomówności i moralności stron i świadków. Na podstawie logiki zeznań i świadectw kwalifikacyjnych, należy - zdaniem Kolegium Sędziowskiego - przyjąć przeciętną, a nawet dobrą wiarygodność Stron i świadków. Daje to podstawy do obiektywnej oceny stanu faktycznego w świetle motywów prawnych mających zastosowanie do zaskarżonego małżeństwa.

Sprawa była prowadzona $\mathrm{z}$ dwóch tytułów: psychicznej (osobowościowej) niezdolności pozwanej do zawarcia małzeństwa i podjęcia istotnych obowiązków małżeńskich (kan. 1095,3 KPK) oraz symulacji zgody małżeńskiej po stronie pozwanej (kan. 1101, 1 KPK). Zdaniem Kolegium Sędziowskiego pierwszy tytuł znajduje pełne uzasadnienie do jego rozpatrzenia i rozstrzygnięcia w świetle zgromadzonego materiału dowodowego, bowiem głównie na skutek patologii osobowościowych pozwanej rodzi się wątpliwość co do zdolności pozwanej do podjęcia istotnych obowiązków małżenskich, a tym samym do realizacji przedmiotu konsensu małżeńskiego. Natomiast co do drugiego tytułu, a mianowicie symulacji zgody małżeńskiej po stronie pozwanej, to w materiale dowodowym nie ma żądnych przekonywających racji pozwalających na rozpatrywanie sprawy $z$ tego tytułu, jednak należy go uwzględnić i rozpatrzyć w świetle tego co powód wnosi.

Kolegium Sędziowskie rozpatrując sprawę i formułując sentencję wyrokową uznalo, że materiał zgromadzony w sprawie jest jednolity, dość obfity (zeznania Stron, ośmiu świadków, dwie opinie psychologiczne biegłego sądowego, jedna w oparciu o akta sprawy, a druga na podstawie badania psychologicznego pozwanej), aczkolwiek zawiera również pewne trudne i nie wyjaśnione kwestie, które nie mialy decydującego wpływu na meritum sprawy i wyroku. Kolegium Sędziowskie podkreśliło na sesji wyrokowej, że w swej analizie materiału dowodowego brało pod uwagę tylko te elementy, które miały wpływ na ważność czy nieważność zawarcia małżeństwa stron z punktu widzenia kanonicznego prawa małżeńskiego i procesowego. Nie brało pod uwagę bezpośrednio okoliczności pozostałych, które zapewne są ważne $\mathrm{i}$ istotne, ale nie dla orzeczenia nieważności czy ważności małżeństwa. Trzeba bowiem wiedzieć, że Sąd Kościelny nie wydaje decyzji rozwodowej, ale orzeka ważność lub nieważność zawartego małżeństwa 
z konkretnych, udowodnionych przyczyn kanonicznych. Wynika więc i analizuje przyczyny i okoliczności, które ewentualnie tę ważność lub nieważność spowodowały, a które istniały w chwili zawarcia małżeństwa. Jest to szezególnie ważne w rozpatrywanej sprawie małżeńskiej, gdyż małżeństwo stron przebiegało zgodnie i bez większych trudności i problemów przez okres prawie trzech lat, dopiero później pojawily się problemy i konflikty, które doprowadzily do zerwania wspólnoty małżeńskiej. Rodzi to zasadnicze pytanie w odniesieniu do osobowości pozwanej w chwili zawierania małżeństwa. Kolegium Sędziowskie zaznaczyło, iż podwójna opinia biegłego sądowego nie ulatwia odpowiedzi na to pytanie, ale je gmatwa, gdyż opinie te są w niektórych elementach sprzeczne i niespójne.

Kolegium Sędziowskie po zapoznaniu się z aktami sprawy, uwagami powoda i pozwanej po publikacji akt sprawy, efektem czego było ponowne powolanie biegłego sądowego (celem przeprowadzenia badania psychologicznego pozwanej), uwagami przedwyrokowymi Obrońcy Węzla Małżeńskiego i po szczególowym przeanalizowaniu całości materiału dowodowego, wnikliwej i szerokiej dyskusji na sesji wyrokowej, wyprowadziło następujące wnioski, jako przesłanki do decyzji wyrokowej:

1. Stosunkowo krótka, bo trwająca niespełna rok, znajomość przedślubna stron przebiegala raczej poprawnie i dobrze. Powód była bardzo zakochany w pozwanej. Wiedzial, że pozwana ma dziecko panieńskie, które obiecał zaakceptować jako swoje i przepisać prawnie na siebie po zawarciu małżeństwa. Posiadanie przez pozwaną panieńskiego dziecka, sprzeciw i odradzanie przez rodziców powoda zawarcia małżeństwa nie przeszkadzało powodowi w kontynuowaniu znajomości i zawarcie małżeństwa. W postawie i zachowaniu pozwanej powód nie dostrzegał niczego niewłaściwego, nieprawidłowego, nie zwracał też uwagi na telefony przed zawarciem małżeństwa, informujące go o nieciekawym towarzystwie w jakim przed ślubem miała się obracać pozwana.

2. Z materiału dowodowego jednoznacznie wynika, iż strony chciały zawrzeć ze sobą małżeństwo. Zarówno powód, jak i pozwana zeznają pod przysięga, że ślubowały szczerze i prawdziwie, dobrowolnie i zgodnie z nauką Kościola. Przez okres prawie trzech lat małżeństwo stron układa się w miarę dobrze i dopiero podczas jednej z kłótni pozwana powiedziala powodowi, że nie chciała w rzeczywistości tego małżeństwa, a ślubowała ze względu na to, aby jej panieńskie dziecko 
miało ojca. Materiał dowodowy, jak i twierdzenia pozwanej wskazują, ze słowa te wypowiedziała w emocjach i nie mają one odzwierciedlenia w rzeczywistości. Nie mogą też być podstawą, jak to sugeruje powód, iż pozwana symulowała konsens małżeński. Nie potwierdza to sama pozwana, ani świadkowie, jak też okoliczności kojarzenia się i zawarcia małżeństwa przez strony.

3. Jest faktem, do czego zresztą się pozwana sama przyznala, iż zdradzała powoda. Miało to jednak miejsce dopiero po okresie dwóch i pół roku, podczas jej wyjazdów do Belgii. Nie ma jednak żadnych dowodów wskazujących na to, że zdrady małżeńskie pozwanej były skutkiem fikcyjnego ślubowania pozwanej. Pozwana ślubowała szczerze i prawdziwie, gdy jednak zmieniły się okoliczności, zmieniła również swoje postępowanie. Brak pieniędzy, zarzuty wobec powoda, że nie pracuje i jest czlowiekiem leniwym i „mało obrotnym”, spowodowały, że zaczęła szukać kogoś innego. Zdrady te nie mają żadnego związku ze ślubowaniem pozwanej wcześniej. Stąd w materiale dowodowym nie ma żadnych dowodów na to, że pozwana całkowicie symulowała zgodę małżeńską lub chociażby częściowo, wykluczając wienność lub nierozerwalność małżeńską.

4. Po zawarciu malżeństwa strony rozpoczęly normalne życie małżeńskie. Po kilku miesiącach wyjeżdżają razem do Belgii do pracy. Później wracają do Polski, a pozwana sama wyjeżdża do Belgii w celach handlowych; jeździ tam bardzo często. W tym czasie powód zajmuje się dziećmi nie mając sposobności podjąć żadnej konkretnej pracy. To zarzuca mu pozwana, jednakże trudno przyznać jej calkowitą rację, gdyż powód zajmując się dziećmi w czasie nieobecności pozwanej, faktycznie nie mial możliwości podjąć jakąś pracę. Zapewne gdyby bardzo zabiegał, mógłby to uczynić. Taki stan rzeczy trwal około trzech lat. Po tym czasie między małżonkami zaczynają się problemy małżeńskie, a powodem ich jest poznanie przez pozwaną innego mężczyznę, z którym zaczyna zdradzać powoda. Pozwana w swoich zeznaniach zarzuca powodowi, że również on zdradzał ją $z$ innymi kobietami. Twierdzenia te jednak nie znalazły potwierdzenia w zeznaniach świadków. Przez okres trzech lat żaden z małżonków nie podnosi żadnych zastrzeżeń odnośnie do funkcjonowania tego małżeństwa. Nawet same strony w swoich zeznaniach stwierdzają, że wszystko przez ten okres przebiegało normalnie.

5. Jak powiedziano w motywach prawnych, osoby zawierające małżeństwo swoimi możliwościami psychicznymi i osobowościowymi win- 
ny gwarantować realizowanie obowiązków małżeńskich i wspólnoty całego życia, jaką jest małżeństwo. Co więcej, winny być zdolne od strony osobowościowej do realizowania przedmiotu zgody małżeńskiej, a więc dóbr małżeńskich takich jak: wspólnota życia, zrodzenie i wychowanie potomstwa, obdarowywanie się szezęśsiem i radością, przyjaźnią, zrozumieniem i dobrem, a także powinny być zdolne do prawidłowych relacji interpersonalnych w swoim małżeństwie. Mając na uwadze przedmiot sporu, a mianowicie czy zaskarżone małżeństwo jest nieważne $\mathrm{z}$ tytułu niezdolności psychicznej (osobowościowej) pozwanej do zawarcia małżeństwa i podjęcia istotnych obowiązków małżeńskich, rodzi się pytanie czy faktycznie pozwana była osobą niezdolną w chwili zawierania małżeństwa do podjęcia obowiązków małżeńskich? Otóż w świetle zgromadzonego materiału dowodowego trudno jest utrzymać tezę o niezdolności psychicznej (osobowościowej) pozwanej. Niezdolność psychiczna do podjęcia istotnych obowiązków malżeńskich charakteryzuje się tym, że nieprawidłowe i patologiczne objawy funkcjonowania w małżeństwie mają miejsce już od samego początku zawarcia związku małżeńskiego. W omawianej sprawie przez okres prawie trzech lat małżeństwo stron przebiegało prawidłowo, same strony to stwierdzają, a braki moralne, zdrady malżeńskie pojawiły się dopiero po tym okresie i dlatego nie mogą być przekonywującym i pewnym dowodem na niezdolność psychiczną (osobowościową) pozwanej.

6. Jest prawdą, że biegła sądowa w swojej pierwszej opinii wystawionej na podstawie akt sprawy stwierdziła, iż pozwana zawierają matżeństwo odznaczata sie cechami osobowości nie w petni dojrzatej emocjonalnie i uczuciowo. Miały za tym przemawiać: jej sposób życia przed ślubem, towarzystwo w jakim się obracała, panieńskie dziecko oraz traktowanie wspólnoty małżeńskiej, a także postawa i zachowanie wysoce nieodpowiedzialne w stosunku do siebie poprzez branie jakiejśs mieszanki leków podrabianych na namiastkę narkotyków. Opinia w jakimś stopniu sugerowała niezdolność pozwanej do podjęcia obowiązków małżeńskich. Według biegłej decydującą i zasadniczą rolę na osobowość pozwanej miał fakt zażywania środków dopingujących. Drogą wnioskowania redukcyjnego, nie popartego tak do końca przesłankami dowodowymi zawartymi w aktach sprawy, stwierdza, że dojrzała osoba, właściwie ukształtowana, mając prawidlową i dojrzałą osobowość, nie doprowadzilaby do uzależnienia od mikstury leków i innych preparatów, które miały destrukcyjny wpływ na jej samopoczucie i ży- 
cie. Sędziowie wobec tej części opinii biegłej uznali, że nie można przyjąć jednoznacznego stwierdzenia biegłej, iż zażywanie preparatów przez pozwaną to skutek wadliwej osobowości, a dojrzała emocjonalnie i osobowościowa osoba tak szybko nie decyduje się na branie tego typu środków. Należy przecież pamiętać, co wynika jednoznacznie z materiału dowodowego, iż powód o zażywaniu przez pozwaną narkotyków dowiedział się dopiero po rozwodzie w 1997 roku. Nie mogły zatem one bezpośrednio oddziaływać na psychikę i osobowość pozwanej sześć lat wcześniej. Domniemanie zatem biegłej, że osoba dojrzała o osobowości prawidłowej, nie sięga tak szybko po narkotyki to hipoteza niczym nie poparta i raczej mylna w swej konstrukcji.

7. Należy wskazać i zauważyć, co wynika jednoznacznie z materiału dowodowego, że środki uzależniające (psychostymulujące) pozwana zaczęla zażywać dopiero po rozwodzie, a więc kilka lat po ślubie, co nie miało bezpośredniego wplywu na jej osobowościową zdolność do podjęcia istotnych obowiązków małżeńskich. Wprawdzie w postępowaniu pozwanej można dopatrzeć się pewnych cech niedojrzałości emocjonalnej, na co wskazuje druga część opinii biegłej sądowej i sama postawa pozwanej (lekceważenie wspólnoty malżeńskiej poprzez nawiązywanie bliskim i intymnych kontaktów z innymi mężczyznami w okresie trwania małżeństwa, używanie środków psychostymulujących własnej produkcji, które spowodowaly u niej toksyczne uszkodzenie ośrodkowego i obwodowego układu nerwowego), to jednak dotyczyły one głównie okresu po zawarciu małżeństwa i nie były nasilone w takim stopniu, aby mogły mieć istotny wpływ na osobowościową zdolność pozwanej do podjęcia i realizowania istotnych obowiązków małżeńskich.

8. W rozpatrywanej sprawie małżeńskiej chodziło o ukazanie i stwierdzenie stanu psychicznego pozwanej w chwili zawierania malżeństwa, a więc w roku 1991. Powód w swojej skardze oraz w zeznaniach stwierdza, że pozwana nie byla emocjonalnie i psychicznie przygotowana do życia we wspólnocie rodzinnej, że jej psychika byta i jest spaczona. Proces o nieważność małżeństwa miał właśnie na celu udowodnienie tych twierdzeń powoda. Materiał dowodowy zebrany w procesie miał właśnie wskazać przesłanki takiego twierdzenia powoda. Tymi faktami byłyby fakty z czasów dzieciństwa i panieństwa pozwanej, zachowania odbiegające od ogólnie uznawanych za prawidłowe i normalne czy też uzasadniające twierdzenie o nieodpowiedzialności czy niedojrzałości pozwanej. Takich faktów proces nie wykazał. Trudno 
natomiast $\mathrm{z}$ faktu zrodzenia dziecka nieślubnego, o którym przez zawarciem małżeństwa powód wiedzial, wyciągać wniosek o niezdolności pozwanej do życia małżeńskiego i funkcjonowania w małżeństwie, kiedy małżeństwo stron przez prawie dwa lata układało się i przebiegało prawidłowo. To samo można odnieść, co już wspomniano wyżej, do faktu brania przez pozwaną środków psychostymulujących, co miało miejsce już po rozpadzie małżeństwa. A więc ich zażywanie i związana z tym nieodpowiedzialność nie miały żadnego wplywu na funkcjonowanie małżeństwa stron. Obecnie pozwana jest poważnie chora i ponosi konsekwencje swej nieodpowiedzialności.

9. Zdaniem Kolegium Sędziowskiego rozpatrującego niniejszą sprawę małżeńską brak jest pewnych, udowodnionych i jednoznacznych dowodów wskazujących na niezdolność psychiczną (osobowościową) pozwanej do zawarcia małżeństwa i podjęcia istotnych obowiązków małżeńskich. Sąd Kościelny rozpatrując sprawę o nieważność małżeństwa nie może ignorować zasady nierozerwalności malżeństwa. A więc nie może orzec nieważności małżeństwa tylko dlatego, że jedno z malżonków tak uważa. Sąd zawsze opiera swe orzeczenie na udowodnionych faktach, w tym przypadku chodziło o fakty uzasadniające twierdzenie powoda o psychicznej niezdolności pozwanej do małżeństwa. Takich faktów Sąd w calym materiale dowodowym zebranym w sprawie nie znajduje. Należy także pamiętać, że Sąd Kościelny nie udziela rozwodu, lecz stwierdza czy w danym przypadku, w momencie zawierania małżeństwa, zostało zawarte prawdziwe małżeństwo, czy też nie. Tak więc późniejsze postępowanie małżonków, jeśli nie ma bezpośredniego związku z momentem zawierania małżeństwa, nie wpływa na orzeczenie nieważności małżeństwa.

\section{Orzeczenie}

Wobec takiego stanu rzeczy, biorąc pod uwagę motywy prawne i faktyczne, które zostały przedłożone w niniejszej sprawie małżeńskiej, Sąd Kościelny Diecezji Włocławskiej, jako Trybunał I Instancji, mając tylko Pana Boga przed oczyma, po wezwaniu Ducha Świętego, w sprawie o nieważność małżeństwa N. N., na pytania procesowe postawione w zawiązaniu sporu, a mianowicie czy zaskarżone małżeństwo jest nieważne z tytulu psychicznej (osobowościowej) niezdolności pozwanej do zawarcia małżeństwa i podjęcia istotnych obowiązków 
małżeńskich (kan. 1095,3) oraz jej symulacji zgody małżeńskiej (kan. $1101,1)$ odpowiada na pierwsze i drugie pytanie negatywnie, stwierdzając, że: nieważność zaskarżonego małżeństwa nie została udowodniona z tytułu osobowościowej niezdolności pozwanej do zawarcia małżeństwa i podjęcia istotnych obowiązków małżeńskich oraz jej symulacji zgody małżeńskiej. 